Steven Paget

Published in War in History, 24:2, 2017, pp.217-235. This is the post-print version and must not be copied or cited without permission.

\title{
Under Fire: The Falklands War and the Revival of Naval Gunfire Support
}

I have always placed a high priority on exercising NGS. All my ships have had the capacity \& I made sure we knew how to use it. NGS became a lower priority for the Naval Staff \& new construction planned had no gun. Op [Operation] Corporate changed all that thinking.

Captain Michael Barrow ${ }^{1}$

The reputation of naval gunfire support (NGS) has waxed and waned since the initial development of the capability. At times, NGS has been considered to have been of supreme importance. At others, it has been viewed as worthless. By the end of the 1970s, there was burgeoning opinion in some circles that NGS had become obsolete. Operation Corporate - the Falklands War - demonstrated that reports of the demise of NGS had been greatly exaggerated.

NGS played a prominent role during Operation Corporate, but it was just one of a multitude of capabilities. As John Ballard put it: 'The British...integrated nearly every tool in the kit bag to mount their operation rapidly and win at the knife's edge of culmination.' ${ }^{2}$ There can be no doubt that the destructive mix of capabilities utilised by British forces was crucial to the success of Operation Corporate. However, due to the inevitable limits of operating so far from home, NGS was often required to redress deficiencies in other fire support capabilities. In the absence of medium and heavy artillery and with the role of aircraft in close air support (CAS) being limited by both competing demands and weather, NGS took on an increasing importance. NGS was used for a range of tasks, including to support assaults and raids, to deceive the enemy and to inflict a psychological strain on Argentine forces. Although it was

\footnotetext{
${ }^{1}$ Written interview with Captain Michael Barrow, conducted by the author, 10 September 2012.

2 John R. Ballard, 'Making the Mix Work: Coalition C2 Interoperability During Recent Operations', 6 ${ }^{\text {th }}$ International Command and Control Research and Technology Symposium, United States Naval Academy, Annapolis, June 2008, p.5.
} 
not decisive, NGS undoubtedly contributed to the success of British forces and helped to save numerous lives. The important role played by NGS in the Falklands War put the capability back in the spotlight and halted - at least temporarily - the planned degradation process, which had been outlined in the 1981 defence review.

\section{The Ever-changing Reputation of NGS}

In the UK defence community, at the turn of the 1980s, there was a growing feeling that NGS was at best a 'black art' and at worst a 'dying art' ${ }^{3}$ The increasing prevalence of missiles, which were believed to be capable of replacing the naval gun for both air defence and surface action, prompted the development of ships without a 4.5 " gun, such as the first and second batches of the Type 22 frigate. ${ }^{4}$ Not only were some ships without a gun, but a number possessed only one and there were no vessels that had more than two. Whilst acknowledging that modern vessels have to adapt to both anti-air warfare (AAW) and anti-submarine warfare (ASW) environments, resulting in diminished space for other armaments, Norman Friedman has warned: 'The number of ships per gun, or per independently-aimable gun, was high [during Operation Corporate], causing congestion in the landing area and exposure to air attack...it is unpleasant to recall that a post-World War II Daring class destroyer...provided three twin 4.5 inch guns on the same displacement as a frigate with one such gun. ${ }^{5}$

Although equipment issues were a foremost concern, proficiency in NGS was also under severe threat. The Royal Navy (RN) had become heavily focussed on the Cold War and the resultant - not to mention more fashionable - activities such as ASW. With corporate thinking focussed on a potential battle against the Red Fleet in the Atlantic, it was easy for the

\footnotetext{
${ }^{3}$ Robert H. Scales, Jr., Fire Power in Limited War (Novato, 1995), p.210.

${ }^{4}$ Michael Evans, Amphibious Operations: The Projection of Sea Power Ashore (London, 1990), pp.163-164.

${ }^{5}$ Norman Friedman, 'Surface Combatant Lessons', in Bruce W. Watson \& Peter M. Dunn, eds., Military Lessons of the Falkland Islands War: Views from the United States (Boulder, 1984), pp.21-22.
} 
requirement for NGS to be overlooked. The future control of NGS was also a potential problem. The defence cuts that were scheduled to take place following the 1981 defence review included a drastic reduction in amphibious forces, which would have - at least in the minds of politicians - made 148 (Meiktila) Commando Forward Observation Battery, Royal Artillery (RA), a dedicated spotting unit, redundant.

The future of NGS was bleak, despite an illustrious past. NGS had an extremely long lineage and had been used to support amphibious assaults since the development of the naval gun. Often overlooked campaigns such as the Ottomans' amphibious invasion of Malta in 1565 was achieved successfully in no small measure to direct naval bombardment. ${ }^{6}$ As technology and gunnery techniques were continually improved, NGS grew in prominence. Naval gunfire did not always live up to expectations, such as the inauspicious employment of NGS at Gallipoli in 1915, but the successful utilisation of the capability during the Second World War confirmed its validity. ${ }^{7}$

The Second World War was arguably the zenith of NGS. Malcolm Muir, Jr. has emphasised: 'Gunfire from ships offshore was one of the great assets making possible Allied amphibious landings in both the European and Pacific theaters. ${ }^{8}$ Indeed, NGS proved to be vital across a range of theatres during the Second World War, although the manner in which the capability was used varied. Whilst sometimes overlooked, a number of lessons emerged from the Mediterranean, which led to a range of developments, including the introduction of maps specifically gridded for spotting, improvements in radio technology and the

\footnotetext{
${ }^{6}$ Jack Beeching, The Galleys at Lepanto (London, 1982), pp.79-98.

${ }^{7}$ At Gallipoli, the flat trajectory of the rounds fired by naval guns meant that little impact was made on Turkish artillery. In addition, observation proved to be difficult owing to the rudimentary technology of the time. Ashley Ekins, 'A Ridge Too Far: The Obstacles to Allied Victory', in Ashley Ekins, ed., Gallipoli: A Ridge Too Far (Wollombi, 2013), p.95.

${ }^{8}$ Malcolm Muir, Jr., 'Naval Gunfire, Shore Support', in Spencer C. Tucker, ed., World War II at Sea: An Encyclopedia (Santa Barbara, 2012), p.538.
} 
deployment of army artillery officers onboard ships. ${ }^{9}$ Those improvements undoubtedly enhanced the provision of NGS in the European theatre, including at Normandy in $1944 .{ }^{10}$

In the Pacific, NGS, in combination with air support, made a significant contribution to amphibious operations, especially as the war progressed. ${ }^{11}$ Improvements implemented after the Battle of Tarawa in November 1943 further increased the effectiveness of NGS and the capability was used to good effect during subsequent Pacific operations. ${ }^{12}$ Notably, the scale and duration of NGS differed during operations in Europe and the Pacific. As a general rule, short intensive bursts were used to paralyse and demoralise the enemy in Europe, whereas much more extensive bombardments were utilised in the Pacific to overwhelm and destroy enemy defences prior to amphibious operations. ${ }^{13}$ Whilst the level of success achieved varied, NGS proved to be a valuable and versatile capability.

The lessons of the Second World War were applied during the Korean War, where NGS was used extensively. Due to the central mountain ranges, Communist forces were compelled to move troops and supplies along the coastlines and in range of naval guns. Although it should be noted that targets were more numerous and more important on the east coast. As the USN was principally responsible for maintaining the blockade on the east coast, they had more opportunity to engage in NGS than Commonwealth and allied ships, which generally operated

\footnotetext{
${ }^{9}$ Barbara Tomblin, With Utmost Spirit: Allied Naval Operations in the Mediterranean (Lexington, 2004), pp.269293; Barbara Brooks Tomblin, 'Naval Gunfire Support in Operation Neptune: A Reexamination', in G. Kurt Piehler and Sidney Pash, eds., The United States and the Second World War: New Perspectives on Diplomacy, War, and the Home Front (New York, 2010), p.196.

${ }^{10}$ For more on NGS at Normandy, see: William B. Kirkland, Jr., Destroyers at Normandy: Naval Gunfire Support at Omaha Beach (Washington DC, 1994).

${ }^{11}$ Trent Hone, 'U.S. Navy Surface Battle Doctrine and Victory in the Pacific', Naval War College Review, Vol.62, No.1, Winter 2009, pp.71-72.

${ }^{12}$ At Iwo Jima, for example, it has been assessed that the preliminary bombardments, particularly those conducted by USS Tennessee and USS Idaho on 18 February 1945, were 'largely responsible for the assault teams' being able to touch down on D-day with few casualties'. Samuel Eliot Morrison concluded: 'In no previous operation in the Pacific had naval gunfire support been so effective as at Iwo Jima.' Samuel Eliot Morrison, History of United States Naval Operations in World War II, Volume 14: Victory in the Pacific, 1945 (Champaign, 2002), p.31.

${ }^{13}$ Christopher Yung, Gators of Neptune: Naval Amphibious Planning for the Normandy Invasion (Annapolis, 2006), p.79.
} 
on the west coast. ${ }^{14}$ USN ships fired over four million rounds and were ably supported by RN, as well as Commonwealth and Allied ships. ${ }^{15}$ The RN was less prolific than the USN, but British ships still fired approximately $161,000,4 ", 4.5 "$ and $6 "$ shells. ${ }^{16}$ The Commander-inChief, US Pacific Fleet (CINCPACFLT) summarised: 'Shore bombardment from naval ships played an important and effective part in the Korean War. The deep water close to the eastern Korea coast plus natural terrain features permitted NGS to be delivered continuously during the entire campaign.' ${ }^{17}$

Although the utilisation of NGS during the Suez Crisis is less well known, the limited use of the capability contributed to the success of the assault on Port Said on 6 November 1956. In conjunction with air strikes, NGS was delivered against the beach at Port Said and a nearby collection of huts, even though the inclusion of the capability proved to be a contentious issue. ${ }^{18}$ Initially, British rules of engagement prevented any guns over 4.5 " calibre from participating in the bombardment. The situation was further complicated when an order was received from cabinet on the night before the assault, which precluded any preliminary naval 'bombardment'. ${ }^{19}$ The decision was made largely for political reasons, but the inherent risks involved in assaulting a fortified position led to the $\mathrm{RN}$ replacing the 'bombardment' with NGS. ${ }^{20}$ In effect, the RN had exploited a difference in terminology to circumvent the restriction

\footnotetext{
${ }^{14}$ It should be noted that the regular exchange of ships allowed navies to operate on alternate coasts on occasion. ${ }^{15}$ Joseph H. Alexander, 'Fleet Operations in a Mobile War, September 1950-June 1951', in Edward J. Marolda, ed., The U.S. Navy in the Korean War (Annapolis, 2007), p.235; Naval Staff History, British Commonwealth Naval Operations, Korea, 1950-1953 (London, 1967), p.298; Eric Grove, 'British and Australian Naval Policy in the Korean War Era', in T.R. Frame, J.V.P. Goldrick and P.D. Jones, eds., Reflections on the RAN (Kenthurst, 1991), p.259.

${ }^{16}$ Naval Staff History, British Commonwealth Naval Operations, Korea, 1950-1953 (London, 1967), p.298.

${ }^{17}$ National Archives and Records Administration, College Park, MD. (NARA), Box 1, Record Group 38, 'Korean War, Commander in Chief U.S. Pacific Fleet Interim Evaluation Report No.1, Covering Period 25 June to 15 November 1950, Volume VI: Combat Operations: Surface and Covering', Undated.

${ }^{18}$ Derek Varble, The Suez Crisis (New York, 2009), pp.62-63.

${ }^{19}$ Keith Kyle, Suez: Britain's End of Empire in the Middle East (New York, 2003), p.456.

${ }^{20}$ Ian Speller, Understanding Naval Warfare (Abingdon, 2014), p.7.
} 
on fire support, but it proved to be a sound military decision, as NGS contributed to the success of the assault.

NGS was also utilised during the Malayan Emergency, but the use of the capability was constrained by the nature of the operating environment. ${ }^{21}$ A January 1956 review by the Director of Operations, Malaya, was representative of the limitations on NGS for much of the campaign: 'Bombardment of the terrorists by ships is a most helpful form of support for ground operations, but unfortunately there are not many opportunities for this type of attack.' ${ }^{22}$ The capacity of the enemy to move further inland and evade NGS limited its usefulness on many occasions. However, during operations where the enemy could be contained, such as Operation Rex, NGS proved to be much more effective. ${ }^{23}$ NGS was used less frequently and more circumspectly after the Korean War, but it remained a useful capability. Indeed, whilst the RN was not involved, the USN and the Royal Australian Navy made extensive use of NGS during the Vietnam War. Although the scale and intended purpose of NGS were sometimes scrutinised, especially during the Korean and Vietnam wars, there was evidence that the capability could prove useful under the right circumstances.

By the onset of the 1980s, the lessons of previous conflicts were perceived to be outdated. In an era of missiles and vastly improved fixed-wing aircraft, the naval gun was increasingly sidelined and began to appear to be a relic of maritime history. Argentina's

\footnotetext{
${ }^{21}$ Steven Paget, 'Old but Gold: The Continued Relevance of Naval Gunfire Support for the Royal Australian Navy', Security Challenges, Vol.10, No.3, 2014, p.76.

${ }^{22}$ TNA, AIR 20/10375, Director of Operations, Malaya, 'Review of the Emergency Situation in Malaya at the End of 1955', January 1956.

${ }^{23}$ During Operation Rex, which was conducted between March and August 1955, the enemy was contained by geography. As the operation took place on the Pengerang peninsula, the targeted enemy - the 9th Independent Platoon, Malayan Races Liberation Army - were more vulnerable to NGS and aerial bombardment, which was especially important as dense jungle limited the involvement of land-based artillery. The success of the operation could not cloud the limitations on NGS during much of the conflict, but it did prove that the availability of the capability was beneficial to ground forces under the right conditions. TNA, ADM 1/26140, Commander-in-Chief, Far East Station, to the Secretary of the Admiralty, 'Joint Operations Against Communist Terrorists in Malaya (Operations "NASSAU” and "REX”)', 30 November 1955; TNA, ADM 1/26140, Office of Flag Officer, Malayan Area to Commander-in-Chief, Far East Station, 'Operation Rex - Report', 17 November 1955.
} 
invasion of the Falkland Islands on 2 April 1982, which prompted the deployment of a British task force to reclaim the islands that were almost 13,000 kilometres away, forced a reconsideration. The nature of the campaign necessitated the involvement of both ships armed with naval guns and NGS forward observers to spot for them.

\section{Call for Fire: The Use of NGS During the Falklands War}

Most notably, NGS was provided in order to support the brigade attacks and raids, but the capability was used for a broad range of reasons during the Falklands War. Prior to the amphibious landing at San Carlos and even afterward, a significant amount of naval gunfire was delivered for the purpose of harassment and interdiction. NGS also was used to deceive and distract the enemy. First and foremost, it was hoped that NGS, in conjunction with other disingenuous measures, might convince the Argentinians that the British would launch their amphibious landing somewhere other than San Carlos. Commodore Michael Clapp, the Amphibious Task Group Commander, has declared: 'The aim was to help the Argentinians in their almost certain assumption that we would land, USMC [United States Marine Corps] style, directly into or very close to Stanley in a once only coup de main (or even a coup de grace!). ${ }^{24}$ Central to that plan was Operation Tornado, a ruse designed to deceive the enemy and conceal the intentions of British forces. Operation Tornado incorporated a number of measures, but particularly naval gunfire. Approximately 100-200 rounds were delivered at irregular intervals and in asymmetric patterns in order to create a sense of confusion. ${ }^{25}$

The manner in which NGS was used was changed as the conflict progressed. Much of the initial harassment fire was conducted during the day, but following the attack on HMS Glasgow on 12 May 1982, it was deemed that the provision of NGS during daylight was too

\footnotetext{
${ }^{24}$ Michael Clapp and Ewen Southby-Tailyour, Amphibious Assault Falklands: The Battle of San Carlos Water (Barnsley, 2007), p.100.

${ }^{25}$ Scales, Jr., Fire Power in Limited War, p.210.
} 
dangerous. As a result, it was decided that the conduct of NGS would occur only at night in order to 'preserve our limited resources and not to take undue risks' ${ }^{26}$ Lieutenant David Tinker, on board HMS Glamorgan, recorded: 'The outcome of it all was that we are not going to do shelling again in daylight, but only at night, when their aeroplanes can't fly for various navigational reasons. It is quite safe then. ${ }^{27}$ The decision to bombard under the cover of darkness was an eminently sensible one and was arguably the only viable course of action. Captain Robert Harmes, who served as a naval gunfire liaison officer (NGLO) during Operation Corporate, stated: 'This situation [the risk from aircraft] dictated the move to nighttime gunfire support which limited the NGFO's [naval gunfire forward observers] observational ability but was outweighed by the safety of naval ships and NGFOs. ${ }^{28}$

Although there was an inevitable decrease in the degree of spotting accuracy at night, the reduction was not significant and much of it could be overcome through the use of illumination rounds. ${ }^{29}$ Almost all of 148 Battery's training for NGS forward observation had been conducted during daylight so an initial adjustment was required. However, in the end, the transition to night time NGS proved to be a relatively smooth process, as outlined by Captain Chris Brown, an NGFO:

It meant that...we had to get used to night vision...we regularly did reconnaissance by day...we confirmed enemy locations during the day so that we could then engage them in darkness. Interestingly enough, as far as I'm aware, it didn't have too much of an impact on the infantry or the supported arm because the infantry, by and large, were quite happy to conduct their operations at night. We sensed that we had an advantage over the enemy at night and therefore, it was, I think, a happy coincidence that the ships were safer on the gunline at night and therefore, naval gunfire was available at night and the infantry felt happier about night so it all came together. ${ }^{30}$

\footnotetext{
${ }^{26}$ David Hart Dyke, Four Weeks In May: The Loss of HMS Coventry, A Captain's Story (London, 2007), p.108.

${ }^{27}$ Hugh Tinker, A Message From The Falklands: The Life and Gallant Death of David Tinker, Lieut. R.N. (Middlesex, 1983), p.178.

${ }^{28}$ Written interview with Lieutenant Colonel Robert Harmes, conducted by the author, 29 October 2012.

${ }^{29}$ Interview with Lieutenant Colonel Mike Morgan, conducted by the author, 24 October 2012.

${ }^{30}$ Telephone interview with Lieutenant General Chris Brown, conducted by the author, 31 August 2012.
} 
As all Brigade attacks were conducted at night, the withdrawal of NGS during the day did not have a detrimental impact on the land forces. Spotters worked around the challenges of operating in the darkness by creating a system for night shoots. NGFOs Captain Hugh McManners and Bombardier Nick Allin devised a system whereby Allin would control the radio by establishing morse communications with the ship until they were close enough to switch to voice communications. McManners would then select a target that could be easily adjusted and which was distant from any settlements, measuring the bearings and distances with special-purpose binoculars. The enemy could be observed using night vision, allowing any corrections to be made. ${ }^{31}$ A combination of night vision, spotting expertise and the desire of land forces to attack at night created the circumstances for the efficient use of NGS.

The destructive capability of NGS and its inherent capacity to restrict the enemy's freedom of movement made an important contribution to the success of Operation Corporate. That said, it should be noted that there were limitations to the destructiveness of NGS, which were recorded by Brigadier Julian Thompson, the Commander of 3 Commando Brigade:

Neither light artillery nor NGS 4.5 inch guns are heavy enough to destroy static defensive positions. Although some fire may kill, wound or demoralize some of the enemy it can be relied upon only to keep the occupants' heads down while the rounds are actually falling; in gunner parlance, to neutralize them... ${ }^{32}$

However, despite the limitations against entrenched enemy positions, NGS was far from impotent. NGS was used to destroy or damage specific targets such as artillery, communications facilities, bunkers, foxholes and trenches. Such was the accuracy of NGS that specific targets could be accurately engaged, including a radar aerial that was 'toppled from its plinth’ by HMS Glasgow. ${ }^{33}$

\footnotetext{
${ }^{31}$ Captain Hugh McManners, Falklands Commando (London, 1984), pp.182-183.

${ }^{32}$ Clapp and Southby-Tailyour, Amphibious Assault Falklands, p.262.

${ }^{33}$ Written interview with Rear Admiral Paul Hoddinott, conducted by the author, 24 August 2012.
} 
A post-operation briefing onboard HMS Glamorgan on 23 June 1982 by Colonel Tom Seccombe, the Chief of staff to Major General Jeremy Moore, and Captain Andy Buchanan, one of the Staff Captains to Admiral Sandy Woodward, the commander of the Carrier Battle Task Group, reported that NGS was responsible for 'causing a huge amount of damage to both material and the mind'. ${ }^{34}$ The performance of HM Ships Arrow, Avenger, Glamorgan and Yarmouth in support of the land forces' night attacks on 11/12 June provided a good indication of the destructive capability of NGS. The 788 rounds fired in support of the attacks 'set fire to a fuel dump close to the racecourse, destroyed a $155 \mathrm{~mm}$ gun and numerous enemy troop positions'. 35

The devastation caused by NGS also proved to be essential in restricting the movement of Argentine forces. Commodore Clapp recalled that when ships were firing on the gunline, one of the most important outcomes was that it 'kept the enemy's heads down at crucial moments' and allowed the British to 'move their own guns, positions etc. without threat of retaliation'. ${ }^{36}$ On a number of occasions, NGS proved to be effective at containing the enemy. During the Fox Bay Raid on 26 May 1982, Captain McManners considered that NGS was pivotal in 'bottling up' the West Falkland garrison. ${ }^{37}$ Additionally, although a small detachment of approximately sixty men at Fanning Head had the capacity to at least hold-up the amphibious operation, NGS, in conjunction with Special Force operations, prevented them from moving on San Carlos. ${ }^{38}$ Ultimately, NGS was crucial in both softening up enemy positions prior to land force attacks and in restricting the enemy's ability to attack and counter-attack.

In retrospect, Brigadier Thompson regretted that even more naval bombardments were

\footnotetext{
${ }^{34}$ Commander Ian Inskip Ordeal by Exocet: HMS Glamorgan and the Falklands War 1982 (London, 2002), p.209.

${ }^{35}$ Clapp and Southby-Tailyour, Amphibious Assault Falklands, p.262.

${ }^{36}$ Written interview with Commodore Michael Clapp, conducted by the author, 9 January 2013.

${ }^{37}$ McManners, Falklands Commando, p.121.

${ }^{38}$ Robert S. Bolia, 'The Battle of Darwin-Goose Green', Military Review, July-August 2005, p.50.
} 
not conducted prior to the Brigade attacks: 'If I had my time again, I'd have tried to have more ships on the gunline during the battles. I'd have had much more preparation on the target before we got there, you know, before the troops arrived, pre-preparation, using NGS, which was very effective'. ${ }^{39}$ Given the shortage of 4.5 " shells that occurred towards the end of the campaign, Commodore Clapp concurred with Brigadier Thompson's assessment: 'a good deal of NGS was wasted in harassing fire before the main attacks. It should have been reserved to give the enemy an almighty, concentrated crack in the immediate run-up to, and during, the Brigade attacks. ${ }^{40}$ On its own, NGS was not a war winner, but in combination with well-planned and aggressive infantry attacks, it proved to be an enabler for success.

Whilst the destructive capacity of NGS had the most tangible impact, the psychological strain inflicted on Argentine troops should not be underestimated. One Argentine solider revealed that NGS effectively reversed the mindset of Argentine forces: 'They began to say the English were going to wipe the floor with us. Until 1 May no one really believed we were going to have to fight. But when the naval attacks began everyone started getting more worried.' Whilst another added: 'We were very demoralized at that time because we felt so helpless, we couldn't do anything. The English were firing at us from their frigates and we couldn't respond. ${ }^{41}$ The likely response of Argentine troops was gauged in advance by the Task Force. In a signal to the Commander-in-Chief Fleet, Admiral Sir John Fieldhouse, outlining the offensive capabilities of the Task Force, Admiral Woodward exclaimed that: 'NGS is a high risk business in daylight but thoroughly good nuisance value at night'. ${ }^{42}$ Throughout the campaign, NGS proved effective in unsettling the enemy.

\footnotetext{
${ }^{39}$ Interview with Major General Julian Thompson, conducted by the author, 26 October 2012.

${ }^{40}$ Clapp and Southby-Tailyour, Amphibious Assault Falklands, p.262.

${ }^{41}$ Scales, Jr., Fire Power in Limited War, p.211.

${ }^{42}$ Lawrence Freedman, The Official History of the Falklands Campaign, Volume II: War and Diplomacy (London, 2005), p.288.
} 
The most obvious example of the demoralising capability of NGS was the capture of South Georgia, known as Operation Paraquet. The extensive bombardment by HMS Plymouth and HMS Antrim was undoubtedly the main factor in inducing the Argentinian troops to surrender. The Argentine forces under Lieutenant Commander Alfredo Astiz surrendered before the fire plan had even been completed and the victory was achieved without loss of life on either side. ${ }^{43}$ Frank Uhlig, Jr., has exclaimed that if it is accepted that Argentine forces surrendered directly as a result of NGS, 'it is the first time, to the writer's knowledge, since the American Civil War that naval gunfire deserved the chief credit for an amphibious success'. ${ }^{4}$

Such was the intimidating psychological impact of NGS that Brigadier Thompson was surprised that the initial plans to capture South Georgia didn't rely on an extensive bombardment: 'The reason they made such a meal of it was because they messed around coming up with over-clever plans, whereas what they should have done was what they did in the end, which is saying: "If you bloody well don't give up, we'll shell you to hell with naval gunfire." And that's what made them change their minds, you know, no cost to us at all. ${ }^{45}$ Indeed, the post-operation report stated: 'Consider NGS effect devastating and surrender indicated before fire plan completed. Demoralisation by NGS absolute. ${ }^{46}$

\footnotetext{
${ }^{43}$ TNA, ADM 202/817, 148 (Meiktila) Commando Forward Observation Battery, Royal Artillery: Operation Corporate Report (Falklands Conflict), 1 July 1982-31 July 1982.

${ }^{44}$ Frank Uhlig, Jr., 'Amphibious Lessons', in Bruce W. Watson \& Peter M. Dunn, eds., Military Lessons of the Falkland Islands War: Views from the United States (Boulder, 1984), pp.62-63.

${ }^{45}$ Initially, British forces had hoped to remain unobserved during their approach and at least until reconnaissance patrols were on the ground. In order to reconnoitre the island, an SAS party was landed on the island at Fortuna Glacier, which they themselves had selected. The insertion was conducted in spite of treacherous weather conditions on 21 April, but an extraction was required on the following morning. During the extraction, two out of the three helicopters crashed due to the conditions but, fortunately, no casualties were suffered. An additional landing using rigid inflatable boats (RIBs) was attempted on the night of 22/23 April but that also proved unsuccessful. D. George Boyce, The Falklands War (Basingstoke, 2005), p.98; Interview with Major General Julian Thompson, conducted by the author, 26 October 2012.

46 TNA, ADM 202/817, 148 (Meiktila) Commando Forward Observation Battery, Royal Artillery: Operation Corporate Report (Falklands Conflict), 1 July 1982-31 July 1982; Nick van der Bijl, Nine Battles to Stanley (Barnsley, 1999), p.75.
} 
Operation Paraquet had demonstrated the continued efficacy of NGS, which helped it to become entrenched as an indispensable means of fire support for the recapture of the Falklands. Not only did it convince Special Forces of the utility of the capability, but 'word had got out to the Royal Marines and the Paras that there's this magic stuff called NGS' ${ }^{47}$ Commodore Clapp discerned that land forces were 'very comfortable with it [NGS] to the extent they demanded more than we could provide. ${ }^{48}$ Clearly, land forces were now aware of the demoralising capacity of NGS and were inclined to maximise their use of it. Brigadier Thompson subsequently proposed on 5 June that: 'We must mallet enemy from now on', in the form of nightly naval gunfire. ${ }^{49}$

The resultant ceaseless shelling meant that, in the words of Major Mike Morgan, the Battery Commander of 148 Battery, 'It never stopped as far as the Argentinians were concerned. ${ }^{50}$ It should be noted that the combination of incessant bombardments and a short conflict contributed to the detrimental psychological impact of NGS. In comparing the effect of harassment fire in Vietnam and the Falklands, Robert Scales deduced:

No matter how effective shell fire might be, in the course of a long war soldiers learn to accommodate and become accustomed to even the most fearsome bombardment, particularly when they realize that shelling often does little harm. But in a short and sharp conflict like the Falklands, the Argentines did not have time to become inured to H\&Is. ${ }^{51}$

Whilst Keith Speed, a former Parliamentary Under-Secretary of State for Defence, has quite reasonably asserted that NGS, 'contributed significantly to the collapse of morale among the Argentinian military', it also provided a huge boost to friendly forces. ${ }^{52}$

\footnotetext{
${ }^{47}$ Telephone interview with Lieutenant General Chris Brown, conducted by the author, 31 August 2012.

${ }^{48}$ Written interview with Commodore Michael Clapp, conducted by the author, 9 January 2013.

${ }^{49}$ Freedman, The Official History of the Falklands Campaign, Volume II, pp.621-622.

${ }^{50}$ Interview with Lieutenant Colonel Mike Morgan, conducted by the author, 24 October 2012.

${ }^{51}$ Scales, Jr., Fire Power in Limited War, p.211.

${ }^{52}$ Keith Speed, Sea Change: The Battle for the Falklands and the Future of Britain's Navy (Bath, 1982), p.143.
} 
In view of the absence of medium artillery, NGS served as an enormous reassurance to British forces. Captain Brown recalled: 'It was very, very obvious to, I think, both friendly forces and to the enemy that they were being either, in the case of friendly forces supported and in the case of the enemy engaged by naval gunfire support and I say that because of this regular clockwork frequency of firing. ${ }^{53}$ Whilst the naval gunfire bombardments were not as effective in the harassment role as originally envisaged or as useful as heavy land-based artillery would have been - if it had been available - there is no doubt that it played a significant role in influencing both friendly and enemy morale.

The most welcome support, from the perspective of the ground forces, was the provision of NGS in direct support of the land battle. NGS was not decisive in itself but it did help to tip the balance in favour of British forces and, in some cases, it was a catalyst for victory. The $3^{\text {rd }}$ Battalion, Parachute Regiment's (3 Para) attack at Mount Longdon on 11/12 June was a classic example. 3 Para's were designated the task of capturing Mount Longdon and they were supported by artillery and NGS from HMS Avenger. The fighting at Mount Longdon descended into a vicious struggle, which lasted throughout the night and resulted in the bloodiest battle of the war. 3 Para's assault met with initial success and they were able to quickly overrun the first line of defence, but they became bogged down by the defensive action of the enemy. Fire support made an essential contribution to the success of the assault, particularly the 165 heavier shells fired by Avenger ${ }^{54}$ In tandem with the support provided by the $105 \mathrm{~mm}$ guns, NGS helped to break the resistance of the enemy. ${ }^{55}$ However, it should be noted that it was aggressive and brave action by the infantry that ultimately won the day.

The non-availability or loss of firepower could and did have a detrimental impact on

\footnotetext{
${ }^{53}$ Telephone interview with Lieutenant General Chris Brown, conducted by the author, 31 August 2012.

${ }^{54}$ Admiral Sandy Woodward, One Hundred Days: The Memoirs of the Falklands Battle Group Commander (Annapolis, 1992), p.326.

${ }^{55}$ David Brown, The Royal Navy and the Falklands War (London, 1987), p.317.
} 
the land battle, which was never more apparent than during the Battle for Darwin/Goose Green, which was initiated at 0200 on 28 May, and was later described by Brigadier Thompson as 'perhaps the most remarkable action fought by a British infantry battalion since the Second World War' ${ }^{56}$ As the $2^{\text {nd }}$ Battalion, Parachute Regiment (2 Para), were without transport, their organic firepower was reduced to two $81 \mathrm{~mm}$ mortars, which made them reliant on the artillery support provided by three guns from 8 Commando Battery, 29th Commando Regiment, RA, and NGS from HMS Arrow. ${ }^{57}$ The largest bombardment conducted by RN ships up to that point in the campaign was scheduled for the night of the attack to divert the attention of the Argentinians away from Darwin and Goose Green. Including the eventual support provided to the attack itself, five ships delivered over 700 rounds that night at targets as diverse as Stanley airfield.

During the battle, HMS Arrow's Mark 8 gun system jammed, precluding the continuation of NGS for two hours, which prior to that point had proven to be very effective. ${ }^{58}$ The lack of NGS, even for that relatively short period was inopportune, as Major Philip Neame, D Company Commander, ended up attacking with limited fire support. ${ }^{59}$ As there was only one barrel on this ship, there was no way to continue NGS, and although Captain Kevin Arnold, the NGFO who was controlling the bombardment, did provide fire support using aircraft, it could not make up the shortfall. ${ }^{60}$ Major Morgan revealed: 'We felt our fingers were slightly

\footnotetext{
${ }^{56}$ Julian Thompson, No Picnic: 3 Commando Brigade in the South Atlantic: 1982 (London, 1992), p.85.

${ }^{57}$ Harry G. Summers, Jr., 'Ground Warfare Lessons', in Bruce W. Watson \& Peter M. Dunn, eds., Military Lessons of the Falkland Islands War: Views from the United States (Boulder, 1984), p.70.

${ }^{58}$ TNA, ADM 202/817, 148 (Meiktila) Commando Forward Observation Battery, Royal Artillery: Operation Corporate Report (Falklands Conflict), 1 July 1982-31 July 1982.

${ }^{59}$ Major-General John Frost, 2 Para Falklands: The Battalion at War (London, 1983), pp.65-66.

${ }^{60}$ To the credit of HMS Arrow, once the crew had addressed the problem, the ship resumed support of 2 Para until she departed at 0845 . Whilst the fault that developed in the gun system captured the most attention, it is worthwhile to note that Arrow remained on station much later than her allotted departure time, despite the obvious risks posed to the ship. TNA, ADM 202/817, 148 (Meiktila) Commando Forward Observation Battery, Royal Artillery: Operation Corporate Report (Falklands Conflict), 1 July 1982-31 July 1982.
} 
burned with having relied on one ship to provide the support for that one attack. ${ }^{91}$ It is hard to definitively gauge the impact of fire support on any battle, but it is clear that the loss was significant. Whether the discontinuation of NGS 'may indirectly have contributed to the check in that unit's initial assault', as suggested by S. Robert Elliot, is debatable, but it was undoubtedly a loss and proved to be a steep learning curve. ${ }^{62}$ It has been contended that firepower 'saved the lives of many infantry soldiers who were obliged to take fewer bunkers and machine gun nests than they would have been without the guns and ships behind them'. ${ }^{63}$ Whilst NGS alone was never going to be sufficient to dislodge Argentinian forces, it proved to be an effective form of fire support, which contributed to the success of the Brigade attacks.

\section{There when you need it: The Limitations of Firepower During the Falklands War}

The intended purpose of NGS varied throughout the conflict, but part of its importance derived from the mere availability of the capability. The availability and, more frequently, the nonavailability of other forms of firepower served as one of the main drivers for the prolific use of NGS. There can be no doubt that land-based artillery in the form of $105 \mathrm{~mm}$ light guns, which were predominantly transported by helicopter, proved to be vital. The official lessons of the Falklands campaign lauded the accurate delivery of 17,500 rounds and concluded that the 'performance was excellent' ${ }^{64}$ However, the performance should not be allowed to mask the absence of medium and heavy land-based artillery, which would have further enhanced the capacity of British forces.

NGS was always going to be an invaluable asset but its importance was increased by

\footnotetext{
${ }^{61}$ Interview with Lieutenant Colonel Mike Morgan, conducted by the author, 24 October 2012.

${ }^{62}$ S. Robert Elliot, 'A Strategic Assessment of the Falklands War', in Brian MacDonald, ed., War in The Eighties: Men Against High Tech (Toronto, 1983), p.12.

${ }^{63}$ Scales, Jr., Fire Power in Limited War, p.233.

${ }^{64}$ Secretary of State for Defence, The Falklands Campaign: The Lessons (London, 1983), p.23.
} 
the fact that it 'fulfilled that role that would traditionally have been provided by medium artillery'. ${ }^{65}$ The 4.5 " naval shell was particularly effective in the Falklands because the high explosive round could be fitted with a proximity fuse, which meant that it could be set to go off on impact or proximity. The prevalence of peat bog in the Falklands made the proximity fuse extremely useful because instead of going off on impact, which would have simply thrown up tonnes of earth, the round could be set to go off at a height of about ten metres above the ground, leading to a devastating outcome. ${ }^{66}$

It was aptly deduced in The Falklands Campaign: The Lessons that: 'The infantry would not have been able to carry their objectives without the support they received from artillery and Naval bombardment', and it should be emphasised that the $8,0004.5$ " rounds proved to be a suitable substitute for medium artillery. ${ }^{67}$ Aside from the weight of firepower, the mobility of NGS provided another advantage over artillery, which needed to be lifted by helicopters that were in short supply, particularly following the loss of Atlantic Conveyor and her cargo of six Wessex, three Chinook and one Lynx helicopter on 25 May.

The Darwin/Goose Green attack by 2 Para demonstrated the potential limitations on artillery due to issues of mobility. Competing requirements meant that the lift capacity had to be divided between other needs and could not be solely committed to moving the artillery. Commodore Clapp documented the dilemma that he faced in regard to transport commitments: 'I would supply helicopters to fly in guns and ammunition but would have to balance this requirement with the offload and first tentative move out towards our already chosen stepping stone of Port Salvador. ${ }^{68}$ The difficulty encountered in moving artillery rapidly was not

\footnotetext{
${ }^{65}$ Telephone interview with Lieutenant General Chris Brown, conducted by the author, 31 August 2012.

${ }^{66}$ Telephone interview with Lieutenant General Chris Brown, conducted by the author, 31 August 2012.

${ }^{67}$ Secretary of State for Defence, The Falklands Campaign: The Lessons, p.17.

${ }^{68}$ Clapp and Southby-Tailyour, Amphibious Assault Falklands, p.170.
} 
sufficiently overcome due to the limited availability of lift assets.

Additionally, there were also constraints on the availability of CAS. The small number of Sea Harriers in theatre and their indispensability in a defensive role meant that their activities needed to be limited. The attack on the airstrip at Goose Green by three Sea Harriers on 25 May, which led to the loss of one aircraft and the death of the pilot, Lieutenant Nick Taylor, prompted Admiral Woodward to conserve the aircraft by limiting their offensive role:

I also decided I should not risk any more of our precious Harriers by allowing them to go out on these high-speed, low-level, cluster-bomb attacks against heavily defended Argentine positions. Quite simply, I could not afford to lose my strictly limited force of air defence aircraft - only about thirty-four in the whole country - on this not-very-effective sort of task. It made better sense to wait for the RAF [Royal Air Force] to provide some Harrier GR3s, not much use at air defence and optimized for ground attack. I resolved that from now on, if they were to bomb at all, it would only be against specific high-value targets or from high level - less accurate, I knew, but less expensive in Sea Harriers. ${ }^{69}$

Both the Sea Harriers and RAF Harrier GR3s significantly contributed to the campaign on land through the provision of CAS, but their role was inevitably limited by weather and the lack of air superiority. Lawrence Freedman noted that: '[Brigadier] Thompson found air support too weather dependent' and 'so sparse as to be a bonus and nothing more'. ${ }^{70}$ Thompson's concerns were mirrored by Major General Moore and his staff, who went to great lengths to ensure that there would be sufficient ships for the provision of NGS, if CAS proved to be lacking during the Brigade attacks. ${ }^{71}$

\section{An Imperfect Asset: The Limitations of NGS}

NGS was not without its problems or limitations in comparison to other forms of fire support.

First and foremost, RN ships had many responsibilities other than the provision of NGS,

\footnotetext{
${ }^{69}$ Woodward, One Hundred Days, pp.18-19.

${ }^{70}$ Freedman, The Official History of the Falklands Campaign, Volume II, p.621.

${ }^{71}$ Scales, Jr., Fire Power in Limited War, p.220.
} 
including AAW and ASW. When fire support could be provided, the timeliness was not always as good as the response of artillery due to the time taken to prepare the ship to fire. In addition, there were occasional problems with the serviceability of the weapons platform. The vulnerability of the ships to air attack also prompted the decision to confine NGS to the cover of darkness. Indeed, it was appreciated that a number of reasons could lead to NGS becoming unavailable; not least the very real risk that a ship might be damaged or sunk. ${ }^{72}$ Ultimately, however, the amphibious nature of Operation Corporate, combined with the absence of heavy artillery and the periodic unavailability of other forms of firepower, ensured that NGS was instrumental in the successful outcome of the war.

There was a feeling that the firepower of the Task Force could have been even further enhanced had the ships been fitted with heavier-calibre guns. Major Morgan declared that: 'In an ideal world, a five-inch is a better gun', as 'it's a bigger bang for your buck', whilst Brigadier Thompson stated: 'Obviously, we would have liked a 5-inch or even 6-inch. That would have been even better but I've got no complaints about it [the 4.5" gun]. ${ }^{, 73}$ Whilst a bigger gun would have been advantageous, there is no doubt that the 4.5" gun delivered a commendable performance during Operation Corporate. That the 4.5" ammunition was sometimes deemed insufficient did not sound the death knell for NGS, but rather indicated that additional firepower was required.

\section{Fighting Fire with Fire: Evaluating the Performance of NGS}

NGS was an important feature of all of the major infantry attacks conducted during Operation Corporate and was, arguably, even more important during operations where manpower was limited. Despite the elongated gap since the last combat use of NGS and the fact that the

\footnotetext{
${ }^{72}$ Freedman, The Official History of the Falklands Campaign, Volume II, p.621.

${ }^{73}$ Interview with Lieutenant Colonel Mike Morgan, conducted by the author, 24 October 2012; Interview with Major General Julian Thompson, conducted by the author, 26 October 2012.
} 
capability had become a secondary concern at best, RN ships excelled in the role during Operation Corporate. From the initial contribution of the "Three Musketeers", HM Ships Alacrity, Arrow and Glamorgan, right through until the end of the campaign, RN ships never let down the land forces. Certainly, the crews of the ships felt that they had done all that they could to contribute to the success of Operation Corporate. Lieutenant Commander Ken Napier, HMS Plymouth's Supply Officer, reflected that 'Plymouth was a Can Do ship, which sounds vulgar, but we were; and when we did things, we did them in style. ${ }^{974}$

Although commentators are often critical of the availability and response time of NGS, RN ships did not hesitate to risk themselves to provide support to land forces. The most obvious example of the willingness of the ships to prioritise support for the battle on land over their own safety was HMS Glamorgan's contribution to the struggle for Two Sisters on 11/12 June 1982. The ship's departure from the gunline was delayed until their support of 45 Commando, Royal Marines, was completed, but the ship was subsequently hit by a shore-based Exocet missile, resulting in the death of fourteen sailors. ${ }^{75}$

That NGS was not always available was no fault of the ships. When a dangerous situation arose on West Falkland, Captain Chris Brown immediately went on the NGS net to request support. The support never arrived but that was because HMS Plymouth, which had been tasked to respond to that request and had immediately got under way, was attacked by Argentine aircraft in the process. In the words of Captain Brown, 'even when there was no planned NGS, the relationship between the services there was such that they were willing to

\footnotetext{
${ }^{74}$ Lt Cdr Ken Napier, 'We Were Determined, We Had The Kit, We Had The Fleet...', in John Winton, ed., Signals from the Falklands: The Navy in the Falklands Conflict An Anthology of Personal Experience (London, 1995), p.107.

75 Brown, The Royal Navy and the Falklands War, p.318; Max Hastings \& Simon Jenkins, The Battle for the Falklands (London, 1997), pp.335-336; Inskip, Ordeal by Exocet, pp.152-153.
} 
risk daylight NGS where that need was sufficiently serious' ${ }^{76}$

Although it is iniquitous to single out individual vessels for praise, particular ships did develop an enviable reputation for gunnery expertise. ${ }^{77}$ HMS Glamorgan, commanded by Captain Mike Barrow, who has been referred to as a 'true sea dog who knew how to fight a ship and get the best out of his men', is remembered for 'distinguishing herself particularly in shore bombardment'. ${ }^{78}$ Indeed, during a post-operation briefing, the ship was informed that: 'Glamorgan was very popular with the troops ashore. Our salvos always landed where and when they were wanted. British troops were quite happy to call down fire from Glamorgan a bare 150 yards away'. ${ }^{79}$ However, there is no doubt that all ships played an invaluable role and that each vessel that engaged in NGS was a credit to the RN. Lieutenant Adrian Nance, the Navigating Officer of HMS Sheffield, proclaimed: 'The RN in general - we learned much on the hoof, I do not think any of the people deployed had much experience and so the learning curve was great. They did well. ${ }^{80}$ The performance of the RN was perhaps best summarised by Major Morgan: 'I can only say, that given all the circumstances, it was nothing short of brilliant...I think, to a man, all the commanding officers of the naval gunships, as I call them, Mark 6 and Mark 8 ships, did a brilliant job...they were prepared to take a risk with the ship to deliver an aim'. ${ }^{81}$

\section{The Importance of Observation: The Fate of 148 Battery}

An inevitable by-product of the confirmation that NGS remained both relevant and useful in modern era was the affirmation that a dedicated and expert spotting force was required to

\footnotetext{
76 Telephone interview with Lieutenant General Chris Brown, conducted by the author, 31 August 2012.

${ }^{77}$ It would be unfair to denigrate the contribution of other ships as it must be remembered that some ships did not possess a 4.5" gun, whilst others were tasked with alternative responsibilities.

${ }^{78}$ Hart Dyke, Four Weeks In May, p.33.

${ }^{79}$ Inskip, Ordeal by Exocet, p.209.

${ }^{80}$ Written interview with Commodore Adrian Nance, conducted by the author, 24 November 2012.

${ }^{81}$ Interview with Lieutenant Colonel Mike Morgan, conducted by the author, 24 October 2012.
} 
control it. That function was fulfilled by 148 Battery. The requirements that needed to be met to join the unit were gruelling and their task was challenging. In contrast, the purpose of the unit was straightforward, as outlined by Captain McManners: 'The main purpose of the Commando Forward Observation Unit is to control the fire of the guns of the Royal Navy, from the ground, and the unit is equipped and trained to be put ashore in every way imaginable so as to be able to do this job. ${ }^{82}$ However, 148 Battery were far from limited to controlling NGS, as the forward observers combined all aspects of indirect fire, including land-based artillery and CAS. NGFOs were capable of 'playing an orchestra', which was 'hugely important' in Operation Corporate, particularly in view of the limited numbers that were deployed for the conflict. $^{83}$

In order to distribute their resources most effectively, 148 Battery was divided into NGFO teams consisting of five men each. Each NGFO team was led by a captain in order to create an 'officer-to-officer relationship' rather than a 'more hierarchical command structure' between the spotter and the senior officer of the supported arm. ${ }^{84}$ The remaining four members of each team were: a bombardier, a leading radio operator (LRO) or radio operator class one (RO1) from the RN, a lance bombardier and a gunner. ${ }^{85}$ The NGFO teams were deployed alongside ground forces and worked directly to the officer commanding the supported arm. The spotting teams were first deployed to support the re-capture of South Georgia and continued to support land operations until the Argentine surrender.

148 Battery had initially been established to comprise seven teams but only five were in existence when the unit deployed to the Falklands. Major Morgan has declared: 'We ran out of NGFO parties. We did not have enough NGFO teams to meet the operational needs. We just

\footnotetext{
${ }^{82}$ McManners, Falklands Commando, p.22.

${ }^{83}$ Interview with Major General Julian Thompson, conducted by the author, 26 October 2012.

${ }^{84}$ Telephone interview with Lieutenant General Chris Brown, conducted by the author, 31 August 2012.

${ }^{85}$ McManners, Falklands Commando, pp.22-23.
} 
didn't have enough people. ${ }^{86}$ On operations, it was sometimes necessary to split the team into two. When NGFO teams were required to separate for a particular mission, the Captain would lead one team, whilst his assistant, the bombardier, would lead the other. ${ }^{87}$ For some operations during Operation Corporate, particularly the raids conducted by Special Forces, two or three people were often sufficient to complete the task. ${ }^{88}$ However, whilst the separation of a team for a short period was standard practice, the shortness of manpower made it necessary to create a makeshift sixth NGFO team, led by a junior NCO, Andy Tatersall, for the initial operations. Whilst Tatersall's performance was exemplary and beyond reproach, it was evident that five teams was not sufficient.

An essential link between the NGFO teams and the RN vessels was provided by NGLOs on board the ships, which was derived from the experiences of the Second World War. ${ }^{89}$ Captain Harmes, outlined the role performed by the liaison officers:

As an NGLO I provided the ship's captain with up to date information on the land battle, the nature of the fire support his ship would be providing and what units they would be firing in support of, communicating with NGFOs and interpreting their requirements. Prior to the commencement of firing, Navy charts had to be overlaid with grid lines, a task undertaken by the Navigation Officer and the NGLO. During firing, as the NGLO, I checked for error using a check map, grid reference of target provided by the NGFO and grid position of ship given by the Navigation Officer. This allowed me to check for gross error using a range arm and protractor. ${ }^{90}$

The NGLO's role was invaluable in compensating for the inevitable inter-service idiosyncrasies. The combination of NGFOs and NGLOs created an incredibly efficient and effective system for the control of NGS. Captain Barrow was forthright in his appraisal of the NGLOs as an 'excellent bunch'. ${ }^{91}$ The small cadre of men from 148 Battery were equally as

\footnotetext{
${ }^{86}$ Interview with Lieutenant Colonel Mike Morgan, conducted by the author, 24 October 2012.

${ }^{87}$ McManners, Falklands Commando, pp.22-23.

${ }^{88}$ Interview with Lieutenant Colonel Mike Morgan, conducted by the author, 24 October 2012.

${ }^{89}$ Interview with Lieutenant Colonel Mike Morgan, conducted by the author, 24 October 2012.

${ }^{90}$ Written interview with Lieutenant Colonel Robert Harmes, conducted by the author, 29 October 2012.

${ }^{91}$ Written interview with Captain Michael Barrow, conducted by the author, 10 September 2012.
} 
important as the ships themselves for the provision of NGS from the commencement to the cessation of hostilities in the South Atlantic.

148 Battery emerged from Operation Corporate with great credit, which was fortunate because their existence had been under serious threat prior to the Falklands War. Indeed, 148 Battery had even received a farewell visit from the director of the Royal Artillery. The survival of 148 Battery can be attributed to two factors. Firstly, as Major Morgan has acknowledged, the nature of the campaign necessitated the involvement of both ships armed with naval guns and NGFOs to spot for them: 'You could not have written a better operational scenario for the use of naval gunfire support. The whole operation lent itself to utilising that defence capability. ${ }^{92}$ Whilst an operational requirement led to the inclusion of 148 Battery, it was the exceptional performance of the unit that led to its retention. In considering the capacity to control land-based artillery, CAS, and especially NGS, Brigadier Thompson was lavish in praise for 148 Battery: 'You knew that these guys were bloody good...They were really competent guys...We had huge faith in what they could do and they did it, they produced the goods, they cut the mustard.' 93 The level of admiration was mirrored on the naval side, with Commodore Clapp adjudging 148 Battery's performance to be 'excellent', whilst also noting that it was 'vital' as the ability to control fire support effectively 'is not something that can quickly be invented' ${ }^{94}$

The invaluable contribution made by NGS was facilitated by the role undertaken by 148 Battery as the efficiency of the gunnery could only ever be as good as the spotting. Captain Brown has remarked: 'I think the conflict saved 148. It saved naval gunfire support. It brought 148 into the spotlight in a way that it had not been in almost...living memory. ${ }^{95}$ It is hard to

\footnotetext{
92 Interview with Lieutenant Colonel Mike Morgan, conducted by the author, 24 October 2012.

${ }^{93}$ Interview with Major General Julian Thompson, conducted by the author, 26 October 2012.

${ }^{94}$ Written interview with Commodore Michael Clapp, conducted by the author, 9 January 2013.

95 Telephone interview with Lieutenant General Chris Brown, conducted by the author, 31 August 2012.
} 
disagree with Major Morgan's conclusion that: 'the Falklands Islands was a very timely operation in terms of retaining a lot of defence capability that might otherwise have been lost', although it must be stressed that it was only the hard work and skill of both 148 Battery and the RN, which saved NGS.

\section{In From the Cold: The Revival of NGS}

Operation Corporate definitively proved the utility of the naval gun or as Anthony Preston, put it: 'The despised gun proved much more important than anyone had predicted.' 96 Preston's appraisal proved to be somewhat of an understatement, with Commodore Clapp asserting that the troops 'loved' the 4.5" gun and Captain Barrow recording that it was 'highly accurate \& effective fire in spt. [support] of troops ashore' ${ }^{97}$ Captain Brown deduced that 'the 4.5 [inch gun] was very effective in the NGS role' because it 'provided what was effectively medium artillery, which under normal circumstances in a land war, would be provided by $155 \mathrm{~mm}$ [guns] ${ }^{98}$ As no $155 \mathrm{~mm}$ artillery was available due to the challenges posed by fighting a war in the South Atlantic, the efficacy of naval guns needed to be reconsidered.

In assessing the capacity of the naval guns utilised during Operation Corporate, Major Morgan professed: 'It was quite accurate. In some cases, it was too accurate. They had to employ a spreading fire to make it less accurate because it was all coming down in the same place. ${ }^{99}$ Indeed, it was gauged that during Operation Corporate, a barrage of twenty-five rounds of 4.5" NGS would be dispersed within an area that was smaller than a tennis court. ${ }^{100}$ The precision of NGS was viewed as one of the advantages of the capability over the alternative

\footnotetext{
${ }^{96}$ Antony Preston, Sea Combat off the Falklands (London, 1982), p.115.

${ }^{97}$ Written interview with Commodore Michael Clapp, conducted by the author, 9 January 2013; Written interview with Captain Michael Barrow, conducted by the author, 10 September 2012.

98 Telephone interview with Lieutenant General Chris Brown, conducted by the author, 31 August 2012.

${ }^{99}$ Interview with Lieutenant Colonel Mike Morgan, conducted by the author, 24 October 2012.

${ }^{100}$ Scales, Jr., Fire Power in Limited War, p.212.
} 
use of artillery. In an ideal situation, Brigadier Thompson would have prioritised land-based artillery over NGS on the basis that it is organic so he could guarantee that it would not be withdrawn or in the worst case scenario - sunk. However, Thompson has acknowledged that: 'Without artillery - either land-based or sea-based - we certainly wouldn't have won that war.' 101

Perhaps the biggest testament to the value and efficiency of the naval gun was the reconsideration undertaken in the design of RN ships. Unlike the previous two batches of Type 22 frigates, the third was fitted with a 4.5 " gun, as was the Type 23 . This was an important development because it reversed a trend that seemed to be impossible to buck. Moreover, the survival of 148 Battery was secured by events in the Falklands. NGS was not high on the RN's list of priorities during the Cold War, but its importance was quickly rediscovered.

NGS was firmly back on the radar of the RN and although the capability would not be used again in anger until the $21^{\text {st }}$ century, it was available when it was required. NGS from HMAS Anzac and HM Ships Chatham, Marlborough and Richmond made a valuable contribution to the success of the assault on the Al Faw Peninsula by the Royal Marines during the 2003 Iraq War. Although the ships fired just 155 rounds across the course of 17 missions between 20 March and 21 March 2003, NGS was undoubtedly a factor in the success of the assault, which was achieved without any combat casualties. ${ }^{102}$ Despite the limited use of NGS in Iraq, it was only eight years until the capability was utilised in combat again. The RN and 148 Battery effectively combined once more in 2011 during Operation Ellamy (the UK's designation for the operation) in Libya. In tandem with French ships, over 500 rounds were

\footnotetext{
${ }^{101}$ Interview with Major General Julian Thompson, conducted by the author, 26 October 2012.

${ }^{102}$ Nick Brown, 'Naval Assets Crucial to Power Projection for Iraq Land Campaign', Jane's Defence Weekly, 23 April 2003; Greg Nash and David Stevens, Australia's Navy in the Gulf: From Countenance to Catalyst (Silverwater, 2006), pp.67-68.
} 
delivered over the course of fifty missions. ${ }^{103}$

The use of NGS during modern campaigns has been significantly more reserved than was the case during the Falklands War. Although the nature of NGS has changed, the Falklands War was pivotal in both the retention of the capability and efforts to hone skills. The proliferation of air-, land- and sea-based precision guided weapons has reduced the reliance on NGS, but it has not eradicated the usefulness of the capability. The lessons of the Falklands campaign remain valid and have shaped the contemporary use of NGS. In an era of projected defence cuts, which could lead to significant reductions in the RN's capacity to conduct operations, it is important that these lessons are not forgotten.

${ }^{103}$ Lieutenant Colonel Tim Wood, 'Gunners Over Libya', The Gunner, December 2011, pp.9-11. 